\title{
THE EFFECT OF DIETARY PROTEIN ON THE UREA CLEARANCE OF CHILDREN WITH NEPHROSIS ${ }^{1}$
}

\author{
By LEE E. FARR \\ (From the Hospital of the Rockefeller Institute for Medical Research, New York)
}

(Received for publication July 21, 1936)

In so-called " pure lipoid nephrosis" in children the urea clearance is frequently elevated markedly above the normal level. There also may be elevated urea clearances in some children with hemorrhagic Bright's disease with a decided nephrotic component. The nature of this paradox of renal hyperfunction in the presence of renal involvement is not entirely clear, and the present work was undertaken in an attempt to elucidate the rôle of the diet in this phenomenon.

The influence of the protein intake on the urea clearance has been studied in adults, but not in children. Cope (1) observed that in adult patients with nephritis, who had a normal or nearly normal clearance, there was a depression of the clearance when the protein intake was lowered from the moderate level of 75 grams per day to 40 grams. He found, however, that there was no increase in the clearance when the protein intake was raised from 75 to 125 grams. In adult patients with chronic renal disease sufficiently advanced to depress the urea clearance consistently below 50 per cent of normal, the effect of lowering the dietary protein was relatively slight. In such patients the urea clearance on 40 grams of protein per day remained about 90 per cent of the clearance on 75 grams. In 1934, Goldring, Razinsky, Greenblatt and Cohen (2) extended Cope's observations to normal men, and came to the same conclusions regarding normal men that Cope arrived at in regard to the patients with unimpaired ability to excrete urea. In Goldring's observations the diet was varied within somewhat greater limits. On the low diet there was observed an average reduction of the clearance of 23 per cent. High protein intakes caused no elevation above the usual normal clearance, even when the protein intake was pushed up to 280 grams per day.

In the present study we have extended to ne-

\footnotetext{
1 Read in abstract before the Society for Pediatric Research May 5, 1936.
}

phrotic children the study of the relation between protein intake and clearance level.

\section{CONDITIONS OF OBSERVATION}

During the experimental period no attempt was made to keep the fat and carbohydrate intakes constant, as previous observations by Page and Farr (3) on the influence of high and low fat diets on plasma lipids had shown these food factors, as well as the total caloric intake, to be without significant influence on the clearance. The salt intake was kept constant throughout the period of observation. The caloric intake was kept relatively constant. The diets were prepared under the supervision of Miss G. Drew and the success in keeping the children eating satisfactorily and contentedly on the various diets is due in no small measure to her efforts.

Four patients with nephrosis, all four years of age, were observed for a period of 54 days on diets with varying protein contents. All of the patients had been observed for several months prior to this study and the maximum variations in the urea clearance, in the absence of complicating intercurrent disease factors, were known. In each patient selected for study, the urea clearance was consistently elevated above normal. Figures 1, 2, 3 and 4 show the clinical, laboratory and diet details relating to these patients since admission.

The changes in clearance reported in this paper were observed over seven successive periods, as indicated in Table I.

To each period several days were allowed for the dietary change to produce its effect on renal function; then urea clearances were observed on two successive days.

Before the second clearance in Period 4 was done, the patient was given enough urea by mouth to bring the blood urea nitrogen up to about the level noted on the high protein diet in the first period, and one hour clearances were run, with blood urea determinations done each hour. The object 


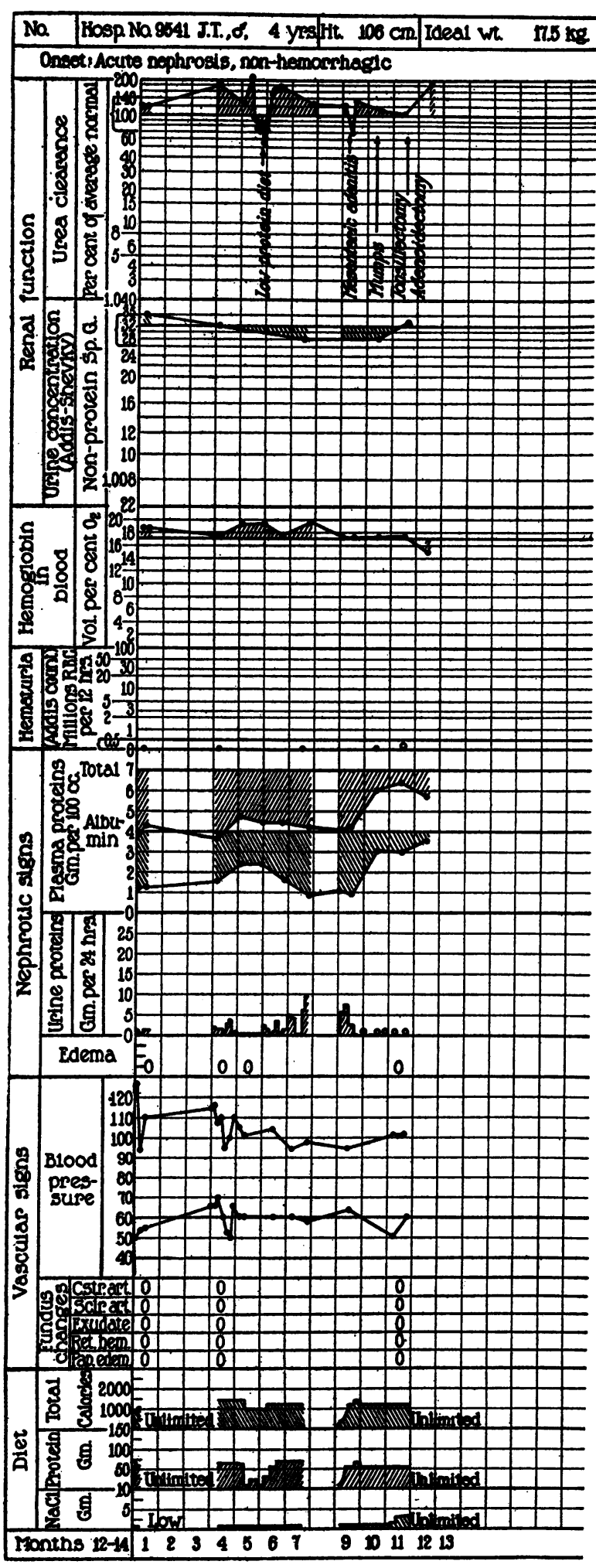

FIG. 1.
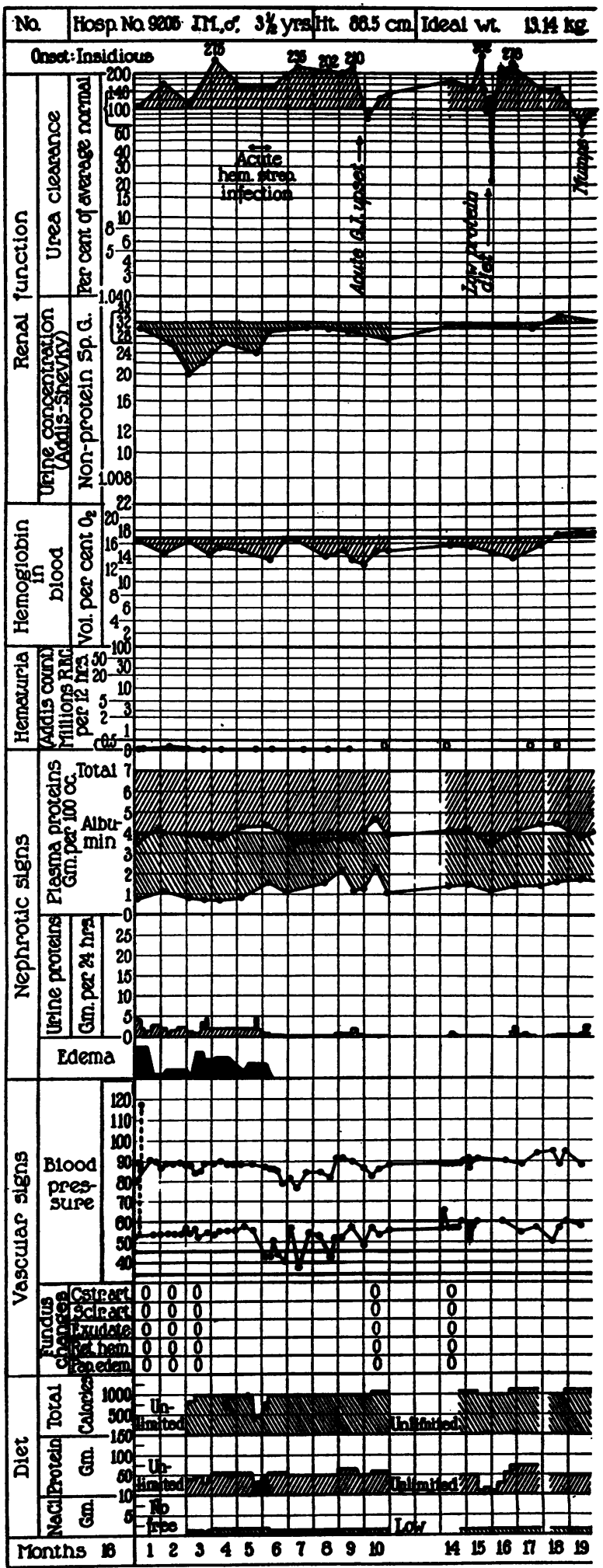

FIG. 2. 

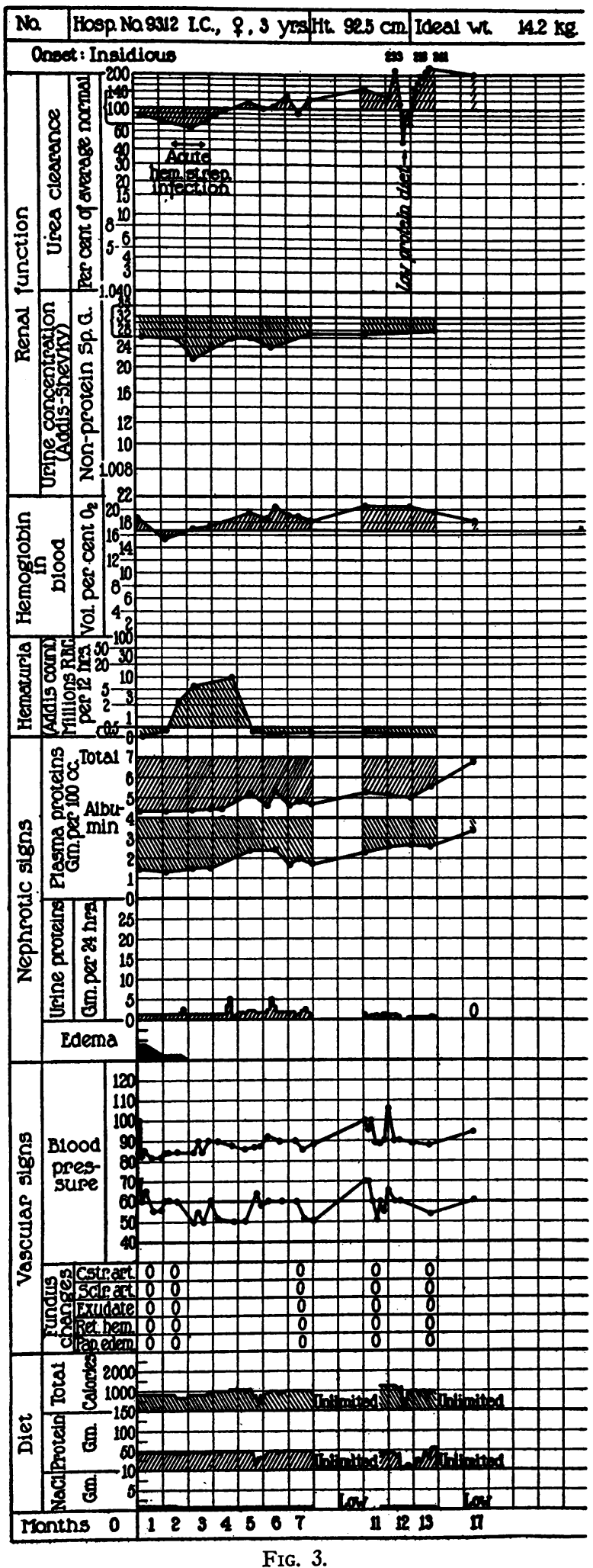
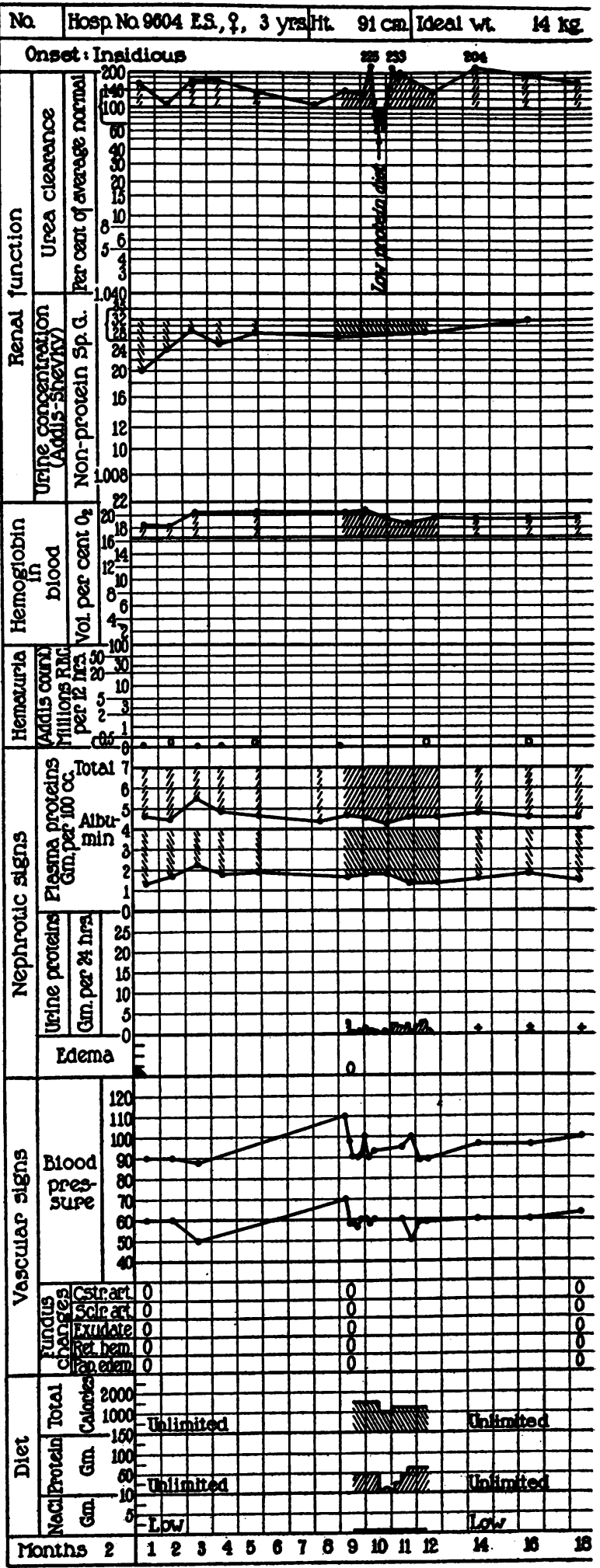

FIG. 4.

Figs. 1, 2, 3, and 4. Clinical Course of Patient Showing Variations of Urea Clearance and Other Clinical Observations Prior to Studies Showing the Effect of Protein in Diet. 
TABLE I

Duration of individual dietary periods and approximate protein intake during each period

\begin{tabular}{ccc}
\hline \hline $\begin{array}{c}\text { Period } \\
\text { number }\end{array}$ & $\begin{array}{c}\text { Duration of } \\
\text { period }\end{array}$ & $\begin{array}{c}\text { Approximate protein } \\
\text { intake per kilo } \\
\text { body weight }\end{array}$ \\
\hline & weeks & grams per day \\
1 & 2 & 3.0 \\
2 & 1 & 0.5 \\
3 & 1 & 1.0 \\
4 & 1 & 0.5 \\
5 & 1 & 2.0 \\
6 & 1 & 3.0 \\
7 & 1 & 4.0 \\
\hline
\end{tabular}

of feeding urea was to ascertain whether the increase of clearance caused by high protein feeding could be duplicated by merely raising the blood urea to the previously existing level. At the same time creatinine clearances were done.

The children were well throughout the entire period of observation, and with one exception (one patient had an acute gastric upset on the second low protein diet lasting one day) took the diet satisfactorily for the entire interval. Throughout this study, with the exception previously noted in Period 4, the clearances were run over two consecutive 12-hour periods instead of the more usual one-hour periods. During part of the studies one-hour clearances were done simultaneously in the usual manner, and these showed changes in the same direction, but the swings were not so wide as in the 12-hour tests. The longer intervals appeared to reflect more accurately the variations in renal function related to the diet. Then, too, over long intervals the collection of urine in children is much more exact. The 12-hour clearances are on the whole somewhat higher on the high protein diet and somewhat lower on the low protein diet than were the one-hour clearances.

\section{ANALYSIS AND CALCULATION}

The analyses of blood and urine urea were done by the hypobromite technique of Van Slyke and Kugel (4). The ammonia nitrogen was not removed from the urine. Consequently, the clearances calculated are approximately those of urea + ammonia. Van Slyke, Page, Hiller and Kirk (5) found that in human subjects clearances of urea + ammonia were more consistent than sim- ple urea clearances, when the ammonia excretion was increased to important proportions.

The urea clearance was calculated by the formula of Möller, McIntosh and Van Slyke (6), with the measured urine volume corrected for surface area according to McIntosh, Möller and Van Slyke (7). The urinary protein was determined by the rapid sedimentation method of Shevky and Stafford (8). Urinary chlorides were estimated by the modified Volhard-Harvey titration as described by Peters and Van Slyke (9). For the first creatinine clearances which were done before this period of observation was commenced but when the patients were on comparable protein diets, the creatinine was determined in the urine colorimetrically by Folin's method (10) and in the blood by the method of Folin and Wu (11). The clearances were calculated as advocated by Rehberg (12). The creatinine clearances done on the low protein diet in this study were carried out according to the method described by Hanzal and Hayman (13). In all instances the normal creatinine clearance was taken as $148 \mathrm{cc}$. for an average adult and the urine flows were corrected for body size in the same fashion as noted above in calculating the urea clearances.

\section{RESULTS}

The results correlated with the diet are shown in Figure 5 and Table II. It will be noted that there is a precipitous fall in the urea clearance when the protein is cut from 3 grams per kilo to 0.5 gram. This fall begins immediately although the minimum level is not reached for about three days. When, subsequently, one gram of protein per kilogram was fed, the clearance was somewhat higher, but when 2 to $2 \frac{1}{2}$ grams per kilogram were fed the urea clearance rose further to near its maximum value. Further increases in protein intake to 3 and 4 grams per kilo affected the urea clearance according to the law of diminishing returns.

The magnitude of these changes is perhaps better brought out by a consideration of the composite curve obtained by averaging the results on all of the children (Figure 6). The extraordinarily high clearances observed on the high protein diets indicate an effect on renal function of altogether greater degree than was observed in 


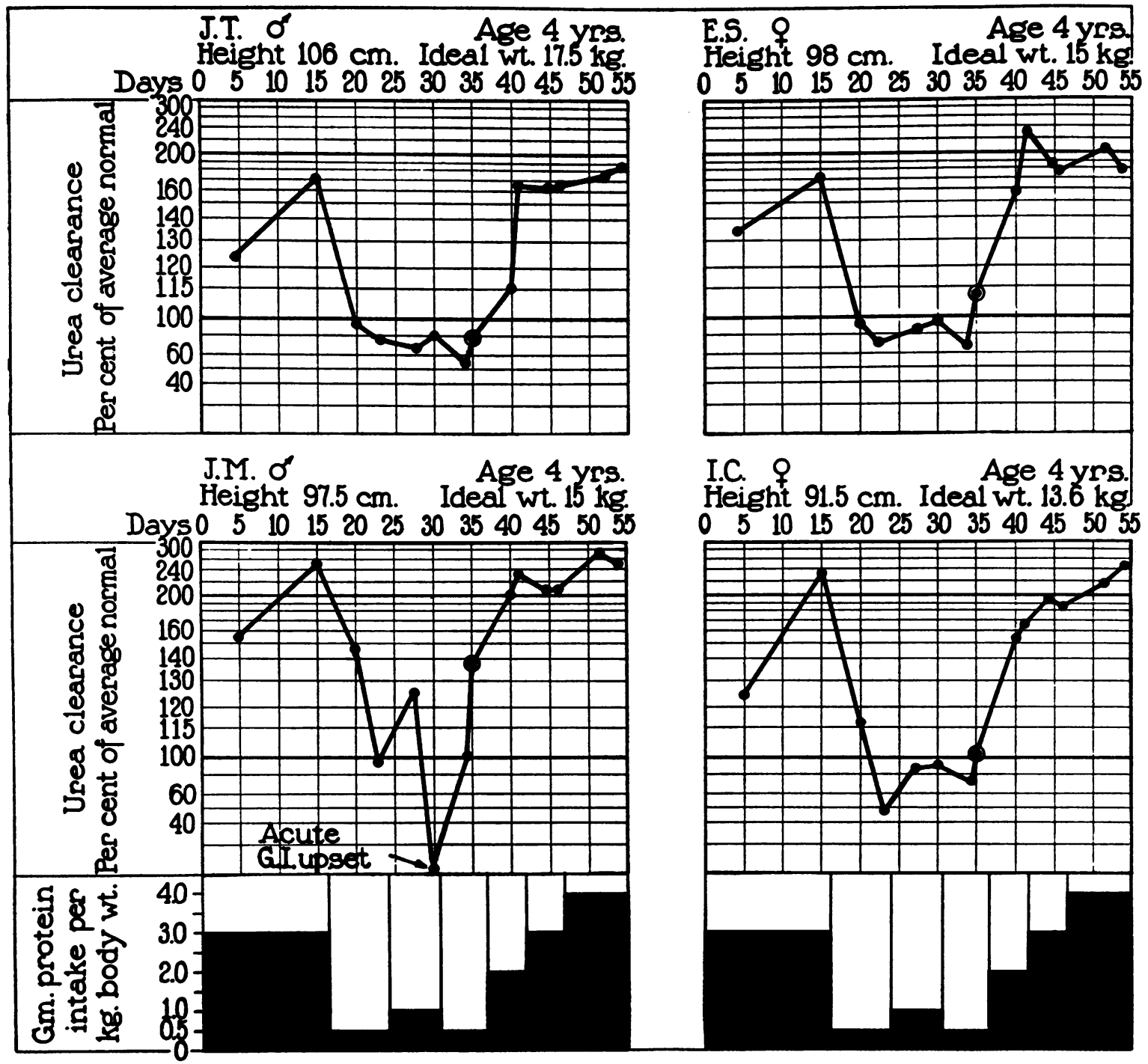

Fig. 5. Relation of 12-hour Urea Clearance to Variations in Protein Intake in the Four Observed Patients.

The encircled point is a one-hour clearance at which time urea and creatinine were fed.

adults, nephritic or normal, by either Cope (1) or Goldring et al. (2).

When sufficient urea was given by mouth to increase the blood urea to a value somewhat higher than that found when the protein intake was at a maximum, the average effect on the clearance was only an increase from 73 per cent normal to 108 per cent normal. This variation is within ordinary normal limits, and the data are not suffciently numerous enough to show whether it has any statistical significance. Compared with the great clearance changes caused by protein feed- ing, the changes caused by urea feeding are insignificant, as has been found in previous reports from this clinic (Møller, McIntosh and Van Slyke (6) ; Van Slyke, Alving and Rose (14)). It appears that the protein effect on the clearance is chiefly due to metabolites other than urea.

The ratio of per cent normal function as measured by the creatinine clearance to the urea clearance (per cent normal function by creatinine clearance/per cent normal function by urea clearance) was 1.46 on the low diet. Creatinine clearances on these patients done previously when an 


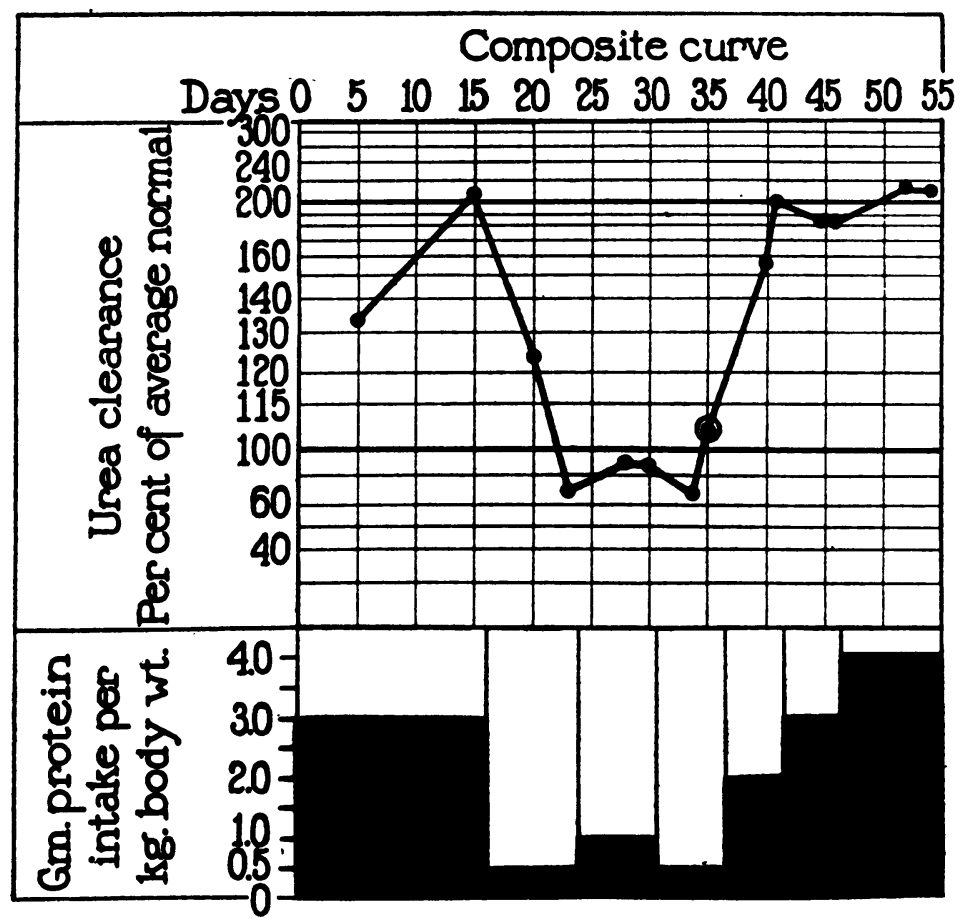

Fig. 6. Composite Urea Clearance Chart Showing Average Change in the 12-hour Urea Clearance with Change in ProTEIN INTAKE.

The encircled point is an average of the one-hour urea clearances, when urea and creatinine were fed.

optimum diet of 3 grams of protein per kilo was being fed showed a ratio of 1.69. The differences in these two ratios are probably not significant; the change in the creatinine clearance was of the same magnitude as the urea clearance.

Since the clearance changes are reversible it is unlikely that the low clearance on the minimum protein diet represents any loss of excretory ability. Van Slyke, Rhoads, Hiller and Alving (15) have shown that in dogs the urea clearance can, as in our patients, be caused to vary over a wide range by shifting the protein intake, and under these circumstances the clearance varied parallel with the renal blood flow. It appears probable that the clearance changes observed in our patients may be similarly due to variations in renal blood flow, caused by the influence of protein metabolites, chiefly other than urea.

The effects of protein intake on urea clearance differ markedly in our 4-year old patients from the effects noted in adults by Cope (1) and by Goldring et al. (2). The chief difference is that in the adults observed by these authors, increase of protein intake to levels markedly above the usual did not cause increase of the urea clearance. Our results with children are much more like those obtained with dogs by Jolliffe and Smith (16) and by Van Slyke, Rhoads, Hiller and Alving (15). Under the influence of maximal variations in protein intake the latter authors obtained in dogs' blood urea clearances varying from 15 to $90 \mathrm{cc}$. of blood per square meter of body surface. Urea as the stimulating factor was excluded in these experiments by feeding urea enough to cause the same rise in its blood concentration noted in the high protein periods; the urea caused no significant increase in renal function or blood flow.

Because of lack of available normal subjects, our observations on children with the nephrotic syndrome lack control observations on healthy children. It therefore remains for future work to ascertain whether the lability of the renal function under varying protein intake observed in our 
patients was due to the nephrotic condition, or whether it is common to normal children of the same age.

One important aspect of this response of the kidney to protein intake is that one must be cautious in interpreting high urea clearances in children unless the dietary history for the preceding few days is known. The difficulties affect only high clearances, as the clearance apparently cannot be made to drop by low protein diets so far as to suggest severe renal damage in its absence.

The secretion of urinary chloride (Table II) fell in these patients at the time the protein intake was diminished. Since all of these patients excrete chloride only with difficulty and in addition were on chloride restricted diets, the actual reduction in chloride excretion was not large but the direction of change was the same in all of the patients. This may in part be the effect of a high

TABLE II

The relation between protein intake, proteinuria, urinary chloride excretion and average urea clearance during period of observation. The chloride intake approximated $1.0 \mathrm{gram}$ per day for each patient

\begin{tabular}{|c|c|c|c|c|c|c|}
\hline$\underset{\text { tient }}{\mathrm{Pa}-}$ & $\begin{array}{c}\text { Approxi- } \\
\text { mate } \\
\text { protein } \\
\text { intake }\end{array}$ & $\begin{array}{c}\text { Dura- } \\
\text { tion } \\
\text { of } \\
\text { diet }\end{array}$ & $\begin{array}{l}\text { Chloride } \\
\text { in urine }\end{array}$ & $\begin{array}{l}\text { Protein } \\
\text { in urine }\end{array}$ & $\begin{array}{c}\text { Average } \\
\text { urea } \\
\text { clear- } \\
\text { ance }\end{array}$ & $\begin{array}{c}\text { Number } \\
\text { of obser- } \\
\text { vations } \\
\text { of } \\
\text { protein- } \\
\text { uria and } \\
\text { urinary } \\
\text { chloride }\end{array}$ \\
\hline & $\underset{\text { per kilo }}{\text { grams }}$ & days & $\begin{array}{l}\text { grams } \\
\text { per day }\end{array}$ & $\begin{array}{l}\text { grams } \\
\text { per day }\end{array}$ & $\begin{array}{l}\text { per cent } \\
\text { normal }\end{array}$ & \\
\hline I. C. & $\begin{array}{l}3.0 \\
0.5 \\
1.0 \\
0.5 \\
2.0 \\
3.0 \\
4.0\end{array}$ & $\begin{array}{r}16 \\
8 \\
6 \\
5 \\
6 \\
6 \\
7\end{array}$ & $\begin{array}{l}0.70 \\
0.06 \\
0.17 \\
0.12 \\
0.61 \\
0.26 \\
0.44\end{array}$ & $\begin{array}{l}1.62 \\
0.09 \\
0.36 \\
0.51 \\
0.80 \\
0.84 \\
0.95\end{array}$ & $\begin{array}{c}179 \\
82 \\
86 \\
74^{*} \\
164 \\
192 \\
230\end{array}$ & $\begin{array}{l}6 \\
2 \\
2 \\
2 \\
2 \\
1 \\
4\end{array}$ \\
\hline J. M. & $\begin{array}{l}3.0 \\
0.5 \\
1.0 \\
0.5 \\
2.0 \\
3.0 \\
4.0\end{array}$ & $\begin{array}{r}16 \\
8 \\
6 \\
5 \\
6 \\
6 \\
7\end{array}$ & $\begin{array}{l}0.40 \\
0.10 \\
0.10 \\
0.01 \\
2.1 \\
0.95 \\
0.44\end{array}$ & $\begin{array}{l}0.44 \\
0.20 \\
0.09 \\
0.20 \\
0.16 \\
0.34 \\
1.07\end{array}$ & $\begin{array}{l}205 \\
120 \\
127 \dagger \\
100^{*} \\
217 \\
208 \\
258\end{array}$ & $\begin{array}{l}6 \\
2 \\
2 \\
2 \\
2 \\
1 \\
4\end{array}$ \\
\hline E. S. & $\begin{array}{l}3.0 \\
0.5 \\
1.0 \\
0.5 \\
2.0 \\
3.0 \\
4.0\end{array}$ & $\begin{array}{r}16 \\
8 \\
6 \\
5 \\
6 \\
6 \\
7\end{array}$ & $\begin{array}{l}0.51 \\
0.10 \\
0.10 \\
0.45 \\
0.85 \\
0.76 \\
0.41\end{array}$ & $\begin{array}{l}2.47 \\
0.53 \\
0.92 \\
0.55 \\
2.7 \\
2.0 \\
2.01\end{array}$ & $\begin{array}{c}151 \\
80 \\
87 \\
65^{*} \\
195 \\
180 \\
190\end{array}$ & $\begin{array}{l}6 \\
2 \\
2 \\
2 \\
2 \\
1 \\
4\end{array}$ \\
\hline J. T. & $\begin{array}{l}3.0 \\
0.5 \\
1.0 \\
0.5 \\
2.0 \\
3.0 \\
4.0\end{array}$ & $\begin{array}{r}16 \\
8 \\
6 \\
5 \\
6 \\
6 \\
7\end{array}$ & $\begin{array}{l}0.88 \\
0.35 \\
0.42 \\
0.03 \\
0.15 \\
1.08 \\
0.92\end{array}$ & $\begin{array}{l}0.60 \\
0.06 \\
0.41 \\
0.35 \\
2.05 \\
0.7 \\
1.72\end{array}$ & $\begin{array}{c}148 \\
87 \\
73 \\
54^{*} \\
142 \\
162 \\
178\end{array}$ & $\begin{array}{l}6 \\
2 \\
2 \\
2 \\
2 \\
1 \\
4\end{array}$ \\
\hline
\end{tabular}

* Does not include 1-hour clearances when urea was fed. † Clearance taken during acute gastro-intestinal upset not included for average. protein diet in assisting in controlling the edema in patients of this type.

Albuminuria decreased rather sharply in these subjects when they were placed on the low protein diets (Table II). This occurred almost immediately after the inception of the low diet. With return to the higher protein intake the albumin excretion came back to its original levels. If one accepts the hypothesis that the albumin in the urine in patients of this type comes largely from the plasma as glomerular filtrate, then any drop in protein excretion such as was seen in this series of observations may be occasioned by decreased glomerular filtrate, and is not necessarily the result of any decrease in permeability of the glomerular tufts to protein. Under these circumstances the daily output of urinary protein would be proportional to the daily volume of glomerular filtrate and not to urine volume. Bing (17) has recently reviewed the literature on proteinuria and has also presented original evidence which supports the belief that protein in the urine is derived almost exclusively from glomerular filtrate, and in a given subject varies proportionally to the glomerular filtrate.

\section{CONCLUSIONS}

In 4 children, aged 4 years, with the nephrotic syndrome, the urea clearance was found to vary markedly with the protein intake. Protein intakes of $0.5,1,2,3$, and 4 grams per kilo per day were accompanied by average urea clearances of 73 , $88,178,184$, and 216 per cent of mean normal, respectively.

The creatinine clearance showed variations similar to those of the urea clearance.

Administration, during low protein periods, of urea sufficient to produce urea outputs like those observed during high protein intake caused relatively slight increase in urea clearance. It appears therefore that the stimulus of renal function by high protein diets was due to products other than urea.

The effect of varying protein intake on urea clearance in our patients was similar to the effect observed in dogs by Van Slyke, Rhoads, Hiller and Alving (15). It therefore appears probable that, as demonstrated in their experiments, the clearance changes indicated parallel changes in renal blood flow. 
The effects of protein intake on urea clearance in our 4-year old patients were much greater in magnitude than similar effects observed in adult human subjects, either normal or with renal disease.

It remains to be ascertained by control observations on normal children whether the observed lability of the clearances is common to young children, or in our patients was due to the combined effect of early age and the nephrotic syndrome.

\section{BIBLIOGRAPHY}

1. Cope, C. L., Studies of urea excretion. VIII. The effects on the urea clearance of changes in protein and salt contents of the diet. J. Clin. Invest., 1933, $12,567$.

2. Goldring, W., Razinsky, L., Greenblatt, M., and Cohen, S., The influence of protein intake on the urea clearance in normal man. J. Clin. Invest., 1934, 13, 743.

3. Page, I. H., and Farr, L. E., The influence of high and low fat diets and thyroid substance on plasma lipids of nephrotic patients. J. Clin. Invest., 1936, 15, 181.

4. Van Slyke, D. D., and Kugel, V. H., Improvements in manometric micro-Kjeldahl and blood urea methods. J. Biol. Chem., 1933, 102, 489.

5. Van Slyke, D. D., Page, I. H., Hiller, A., and Kirk, E., Studies of urea excretion. IX. Comparison of urea clearances calculated from the excretion of urea, of urea plus ammonia and of nitrogen determinable by hypobromite. J. Clin. Invest., 1935, 14, 901.

6. Möller, E., McIntosh, J. F., and Van Slyke, D. D., Studies of urea excretion. II. Relationship between urine volume and the rate of urea excretion by normal adults. J. Clin. Invest., 1928, 6, 427.
IV: Relationship between urine volume and rate of urea excretion by patients with Bright's disease. J. Clin. Invest., 1928, 6, 485.

7. McIntosh, J. F., Möller, E., and Van Slyke, D. D., Studies of urea excretion. III. The influence of body size on urea output. J. Clin. Invest., 1928, 6, 467.

8. Shevky, M. C., and Stafford, D. D., A clinical method for the estimation of protein in urine and other body fluids. Arch. Int. Med., 1923, 32, 222.

9. Peters, J. P., and Van Slyke, D. D., Quantitative Clinical Chemistry. Volume II. Methods. The Williams and Wilkins Co., Baltimore, 1932, p. 833.

10. Folin, O., On the determination of creatinine and creatine in urine. J. Biol. Chem., 1914, 17, 469.

11. Folin, O., and $\mathrm{Wu}, \mathrm{H}$., A system of blood analysis. J. Biol. Chem., 1919, 38, 81.

12. Rehberg, P. B., Studies on kidney function. I. The rate of filtration and reabsorption in the human kidney. Biochem. J., 1926, 20, 447.

13. Hanzal, R. F., and Hayman, J. M., Jr., A simplified method for measurement of creatinine clearance. Proc. Soc. Exper. Biol. and Med., 1934, 31, 730.

14. Van Slyke, D. D., Alving, A., and Rose, W. C., Studies of urea excretion. VII. The effects of posture and exercise on urea excretion. J. Clin. Invest., 1932, 11, 1053.

15. Van Slyke, D. D., Rhoads, C. P., Hiller, A., and Alving, A., The relationship of the urea clearance to the renal blood flow. Am. J. Physiol., 1934, $110,387$.

16. Jolliffe, N., and Smith, H. W., The excretion of urine in the dog. I. The urea and creatinine clearances on a mixed diet. Am. J. Physsiol., 1931, 98, 572.

II. The urea and creatinine clearance on cracker meal diet. Am. J. Physiol., 1931, 99, 101.

17. Bing, S., Studies on Proteinuria. Levin and Munksgaard Einar Munsgaard, Copenhagen, 1936. 